\title{
Modelling of Solar panel in MATLAB for Solar Water Pumping System
}

\author{
Anoop J R, PG Scholar, Sree Buddha College of Engineering, Pattoor, Kerala, India \\ Reema N, Asst. Professor, Sree Buddha College of Engineering, Pattoor, Kerala, India
}

\begin{abstract}
Solar Panel is an important development for the new world, now many scientific studies are taking place in the field of solar panel. The biggest problem now the world facing is energy crisis, so it is very important to use an alternative form of energy. The solution for energy crisis leads to the development in the use of solar powered energy generation systems and this is used for the irrigation purposes also. MATLAB is the best environment for studying the efficiency and analysis of the circuit, thus the modelling of solar panel in MATLAB is explained here. The output of solar panels are very low this can be improved by using MPPT control techniques, thus the efficiency of the system will become high.
\end{abstract}

Index Terms-Solar Panel, MATLAB

\section{INTRODUCTION}

In solar water pumping system the input energy is extracted from the sun by using the photovoltaic panels. The modeling and simulation of solar panel is introduced here along with, the different types of panel and comparison of solar powered irrigation system with conventional systems. There are different types of Solar Water Pumping Systems now exist such as Battery coupled solar water Pumping System, Direct Coupled Solar Water Pumping System and Grid Connected Solar Water Pumping System, these are shown in fig 1
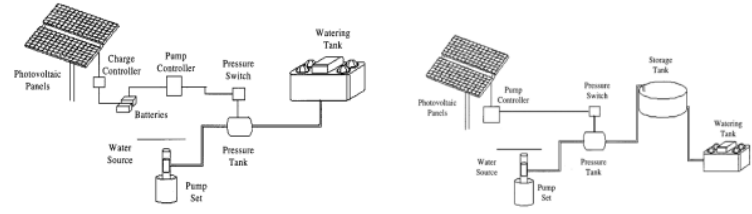

Fig.1 Solar Water Pumping Systems

\section{TYPES OF SOLAR PANEL}

The working of solar panels is to convert the photons to electricity and this is achieved by the solar cells in the panels. The basic part in the solar panel is silicon cell, but there are different types of solar cells available such as polycrystalline, amorphous, monocrystalline and hybrid type.

Monocrystalline solar cells are taken from the artificial-grown crystalline and these are thin silicon wafers. The efficiency of these types of cells are between $15-24 \%$. Polycrystalline cells are also thin wafer of silicon from artificial crystalline but the cells are not single, they are made by multiple interlocking with an efficiency of 13-18\%. Amorphous solar cells are cheaper it is formed by placing a thin layer of silicon on a substrate, this helps for more flexible type panel and can be used for winter seasons. The efficiency is low (7-9\%) when compared to the other two types. Hybrid solar cells are the combination of amorphous and monocrystalline solar cells. This the most efficient type of solar cell and this can withstand very high solar radiation power.

\section{SOLAR WATER PUMPING SYSTEM}

Solar energy is a renewable energy resource and it has many advantages such as its intermittency of sunlight, inexhaustible, widely available, ultimate source of energy and free of cost. For irrigation purposes diesel powered systems are present in ancient days but when it is compared with solar water pumping system, the most efficient one is solar powered irrigation system itself. The table 1 gives the comparative report about the solar powered irrigation system with diesel powered systems.

Table 1 Comparison of solar powered with diesel powered pump

\begin{tabular}{|l|l|lr|}
\hline Features & \multicolumn{1}{|c|}{$\begin{array}{c}\text { Solar } \\
\text { Powered Pump }\end{array}$} & \multicolumn{1}{|c|}{$\begin{array}{c}\text { Diesel Powered } \\
\text { Pump }\end{array}$} \\
\hline Investment & $\begin{array}{l}\text { High initial } \\
\text { investment }\end{array}$ & $\begin{array}{l}\text { Low initial } \\
\text { investment }\end{array}$ \\
\hline Running Cost & $\begin{array}{l}\text { Negligible } \\
\text { maintenance } \\
\text { and running } \\
\text { cost and }\end{array}$ & $\begin{array}{l}\text { Very } \\
\text { maintenance } \\
\text { running cost }\end{array}$ \\
\hline Maintenance & $\begin{array}{l}\text { Cleaning of } \\
\text { panel can be } \\
\text { achieved } \\
\text { through local } \\
\text { labour }\end{array}$ & $\begin{array}{l}\text { Minor \& } \\
\text { service, periodic } \\
\text { overhauling needs } \\
\text { skilled labour }\end{array}$ \\
\hline Hazardousness & $\begin{array}{l}\text { Green energy } \\
\text { pollution free }\end{array}$ & $\begin{array}{l}\text { Fire hazardous and } \\
\text { polluted }\end{array}$ \\
\hline
\end{tabular}

\section{MODELLING OF SOLAR PANEL}

\section{A.EQUATIONS}

The PV module can be modelled by two different types such as current input module or voltage input module [5]. The parameters taken for the modelling of the solar panel 
are short circuit current, open circuit voltage, rated current at maximum power point and rated voltage at maximum power point. The modelling of the panels are done in standard test conditions of about $25^{\circ} \mathrm{C}$ and the temperature effects are not included in the model. The equivalent circuit for the PV cell is shown in fig.2

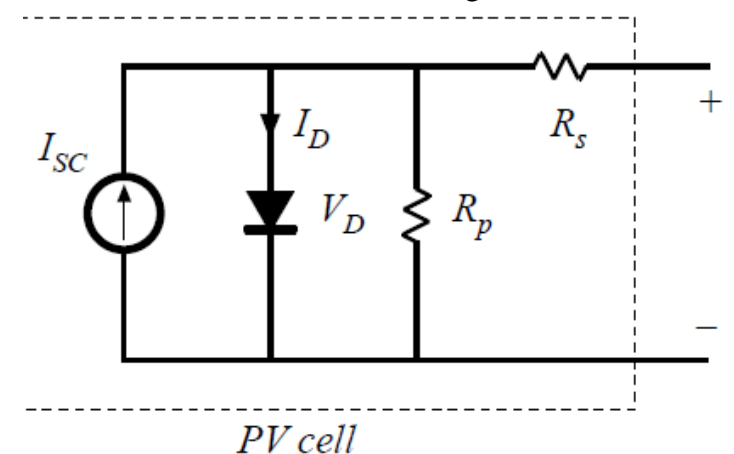

Fig 2 Equivalent circuit of solar cell

By applying Kirchhoff's current law

$$
I_{S C}-I_{D}-\frac{V_{D}}{R_{P}}-I_{P V}=0
$$

By applying the voltage law voltage of cell is

$$
V_{P V \text { cell }}=V_{D}-R_{S} I_{P V}
$$

The current through diode is taken as

$$
I_{D}=I_{O}\left(e^{V_{D} / V_{T}}-1\right)
$$

The number of cells are calculated by, $N_{S}=V_{O C} / 0.61$

The thermal voltage $V_{t}$ is taken 26e-3

The equation for irradiation to short circuit gain is,

$$
G=I_{S C} / 100
$$

The cell voltage at maximum rated power is,

$$
V_{M P C}=V_{R} / N_{S}
$$

The cell voltage at open circuit condition is,

$$
V_{O C C}=V_{O C} / N_{S}
$$

The load resistance at maximum power is,

$$
R_{M P P}=V_{M P C} / I_{R}
$$

The diode current at maximum power point is,

$$
I_{d m}=I_{S C}-I_{r}-V_{d m} / R_{P}
$$

The reverse saturation current is,

$$
I_{O}=\frac{\left(I_{S C}-\frac{V_{O C C}}{R_{P}}\right)}{e^{\frac{V_{O C C}}{V_{T}}-1}}
$$

The voltage across diode at maximum power point is,

$$
V_{d M}=V_{T} * \log \left(I_{d m} / I_{O}+1\right)
$$

The series cell resistance can be calculated by,

$I_{S C}-$ Short circuit current

$$
R_{s}=\frac{V_{d m}-V_{m p c}}{I_{r}}
$$

$V_{o c}$ - Open Circuit Voltage

$R_{s}$ - Internal series resistance

$R_{p}$ - Shunt resistance of the diode

$I_{D}$ - Current through diode

$V_{D}$ - Voltage across the diode

$V_{P V}-$ Output voltage of PV cell

$I_{P V}-$ Output current of PV cell

$G$ - Short Circuit gain

$N_{S}-$ No of series cells

\section{B.MODELLING OF SOLAR PANEL IN MATLAB}

The solar panel is modeled in MATLAB Simulink as shown in Fig 3 with the following parameters.

The parameters used for modeling are,

Short circuit current, $\mathrm{I}_{\mathrm{sc}}=5.45 \mathrm{~A}$

Open circuit voltage, $\mathrm{V}_{\mathrm{oc}}=22.3 \mathrm{~V}$

Rated current at maximum power point, $\mathrm{I}_{\max }=4.95 \mathrm{~A}$

Rated voltage at maximum power point, $\mathrm{V}_{\max }=17.2 \mathrm{~V}$

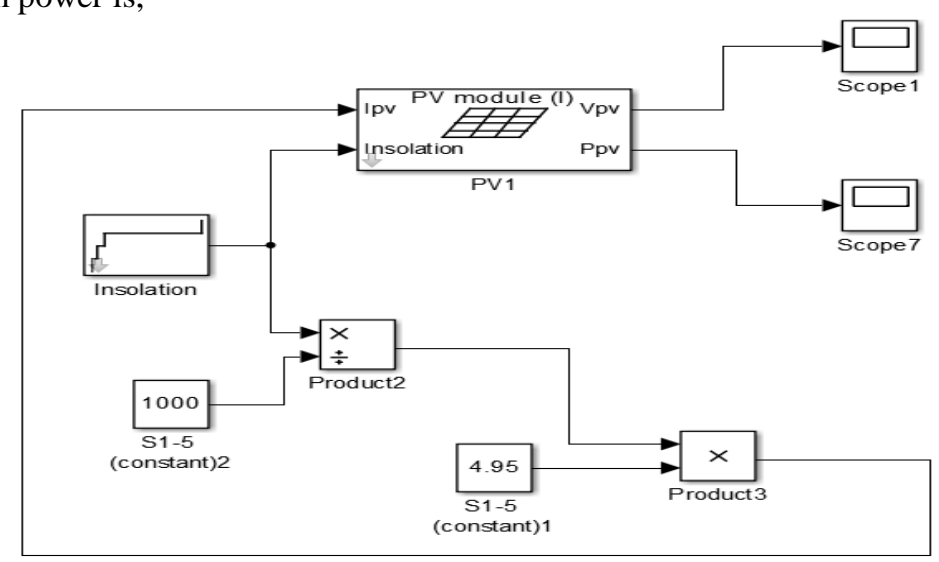

Fig 3 Solar Panel Modeled in MATLAB

From the figure it can be seen that a variation in insolation is given as input to the solar panel, under test conditions the short circuit current for a insolation of 1000 $\mathrm{W}$ is taken as 4.95 and by using the value of current is find out for different value of insolation. The model of PV developed in MATLAB is shown in fig. 4. The modeling equations are specified above and the simulation is done for $5 \mathrm{sec}$.

As time changes the insolation of the sun also changes, so for modelling of panel corresponding change in insolation is given as input. The input insolation power given to the panel is shown in fig. 5 . 


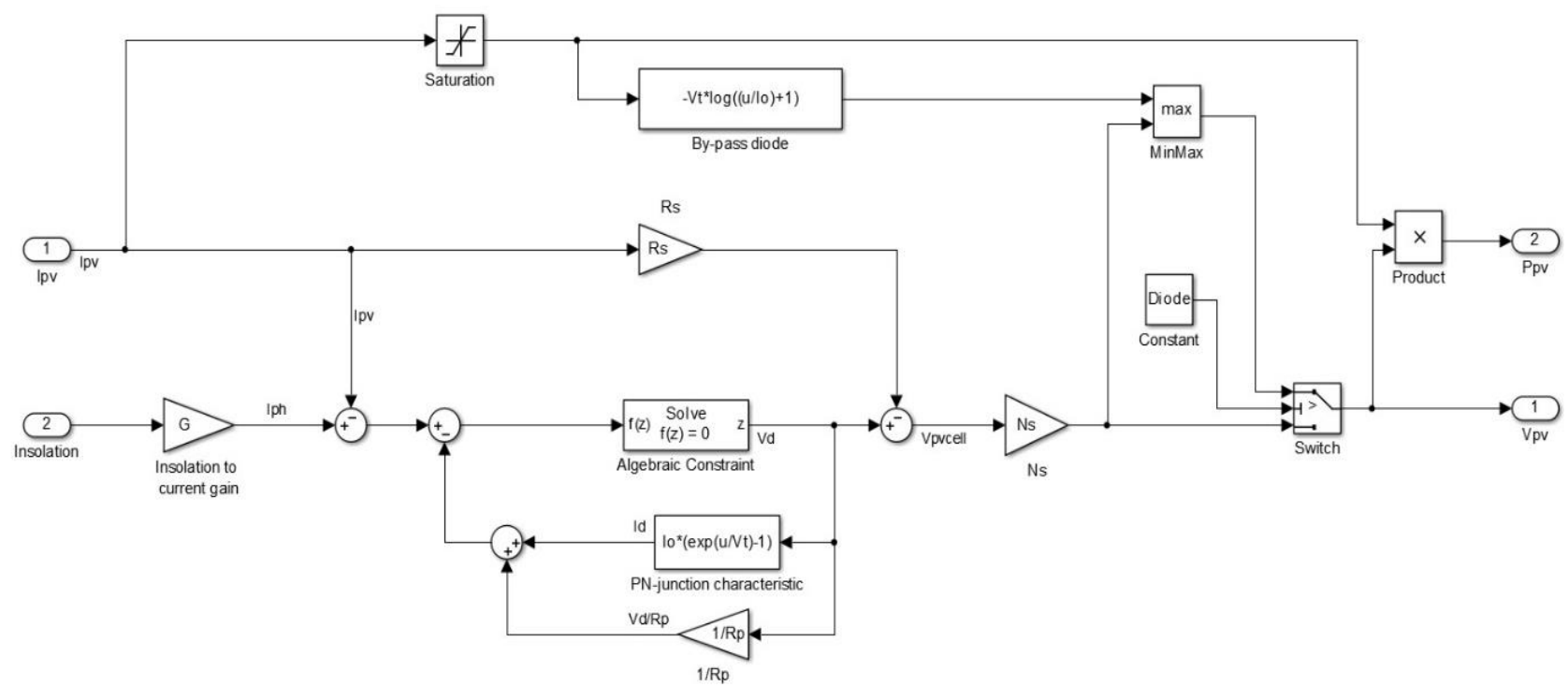

Fig 4 MATLAB model of the PV Panel

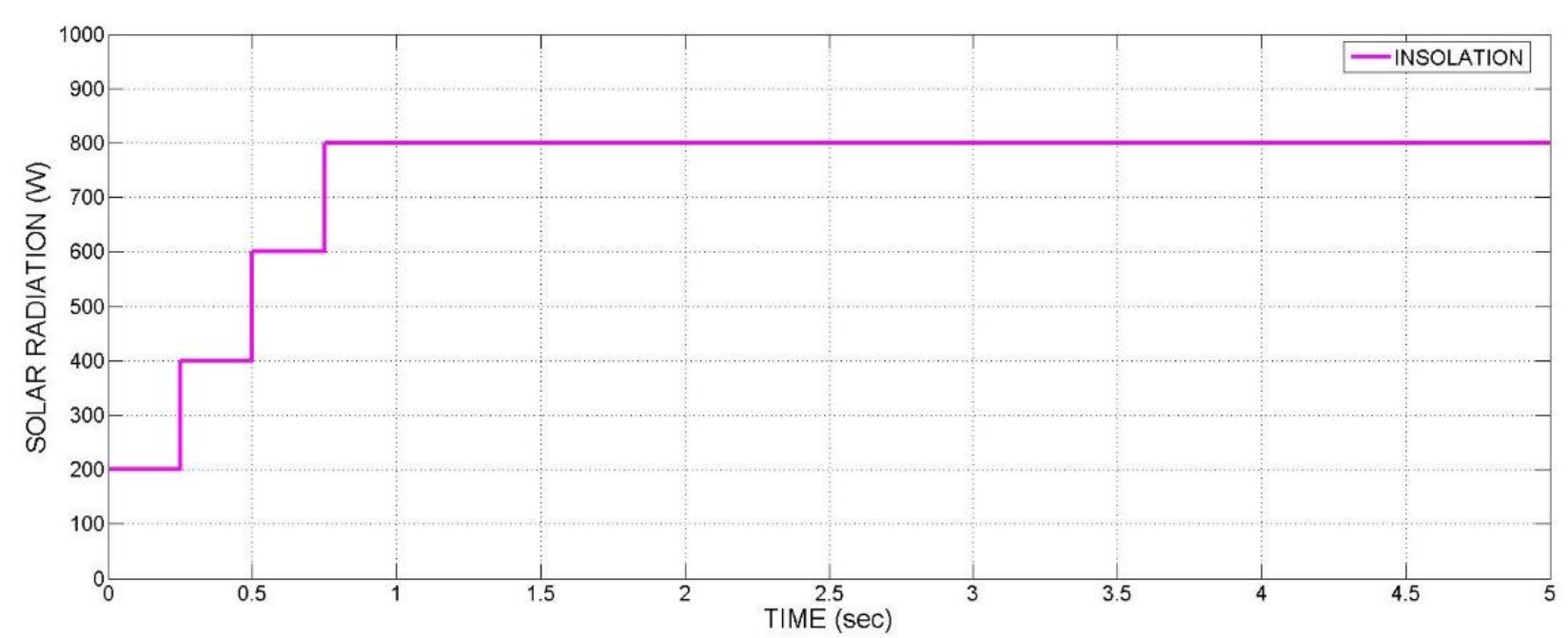

Fig 5 Solar Insolation Input to the PV Panel

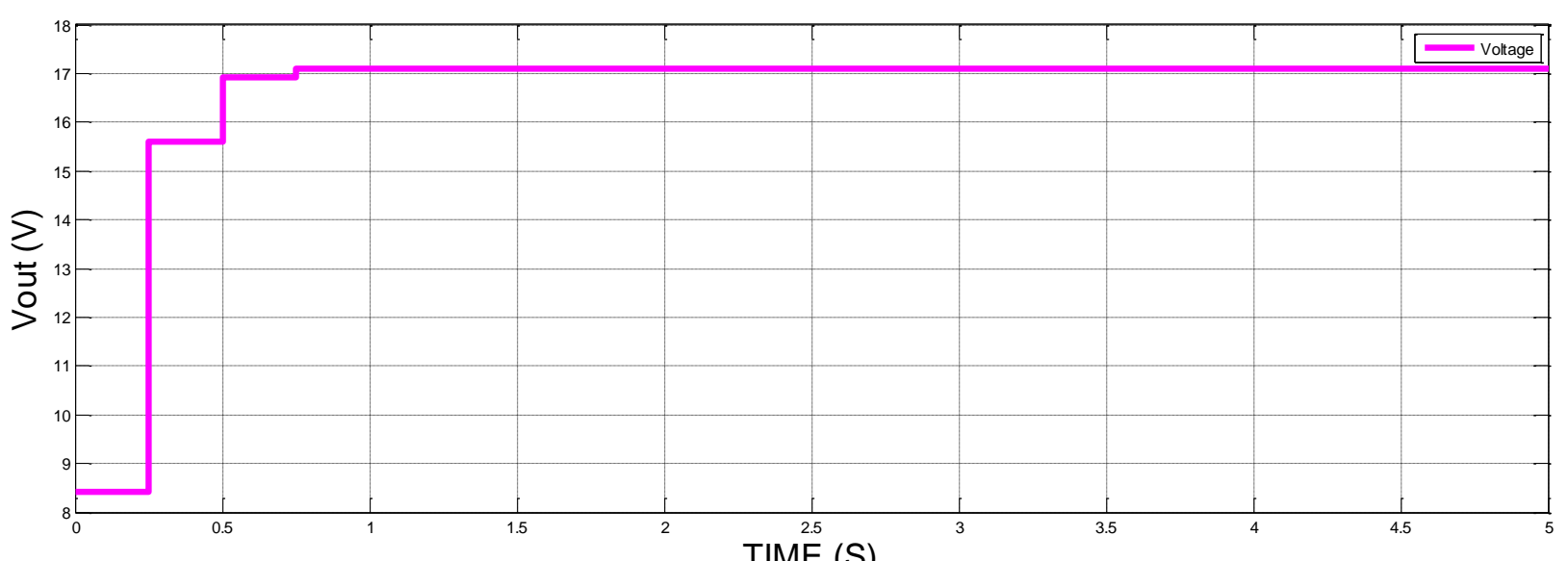

TIME (S)

Fig 6 Output voltage response of solar panel

In practical circuits the maximum power from the sun can be achieved by incorporating the stepper motor control of panels by sensing the direction of insolation. Thus the efficiency of the system will be increased. As there is change in input insolation given there should be change for the output power and voltage in various instants of time. The output voltage response of the panel is shown in fig. 6 The changes in output voltage response is shown in figure, as the time changes there occurring corresponding changes in output voltage. After $0.75 \mathrm{sec}$ the insolation is constant and the output voltage is also constant, for a constant insolation output voltage is also constant. The 
power response of the solar panel is shown in fig 7 , the changes in output power can be seen from the figure. After constant insolation power output is also constant after $0.75 \mathrm{sec}$.

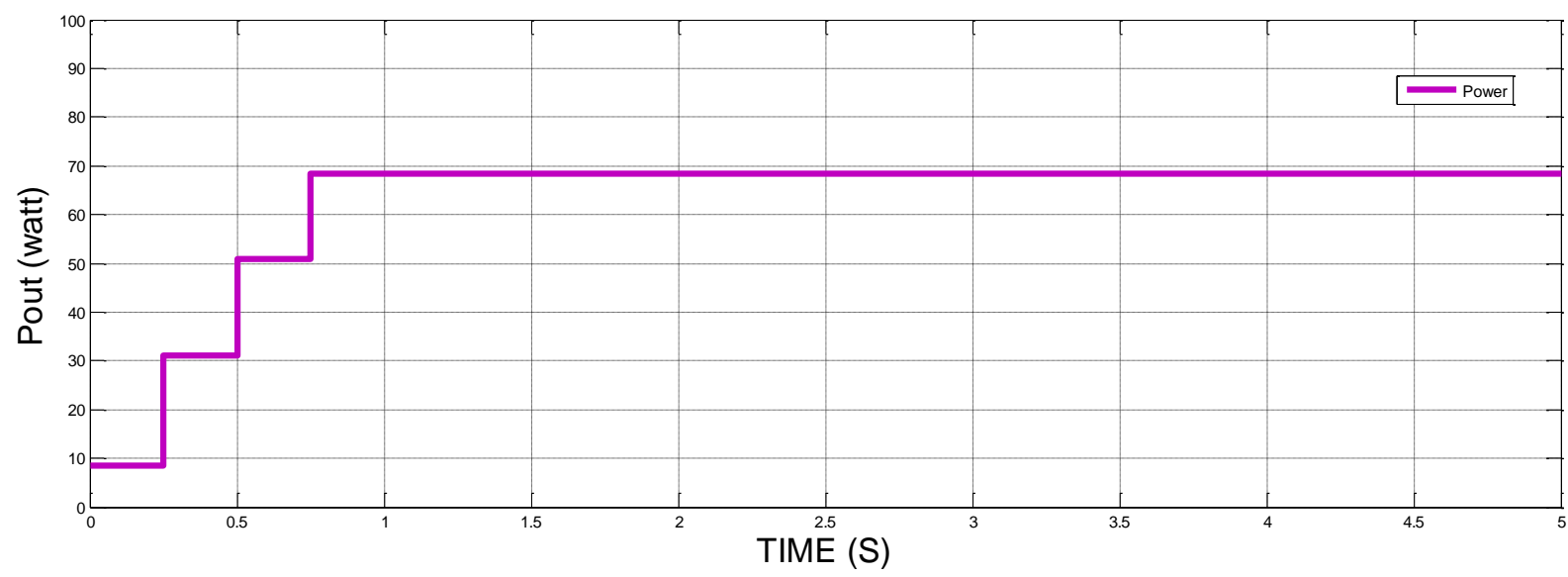

Fig 7 Output Power response of solar panel

\section{V.CONCLUSION}

Solar panel is a best alternative for the use of renewable energy resources. Now there are many developments taking place in this field, here the different types of solar

\section{REFERENCES}

[1] Joao Victor Mapurunga Caracas, Muis Felipe Moreria Teixeira, "Implementation of a High ficiency, High Lifetime, and Low Cost Converter for an AutoNomous Photovoltaic Water Pumping System", IEEE Transactions of Industry Applications, Vol.50, No.1 Jan/ Feb 2014.

[2] Mick Morris ,"A cost and reliablity comparison between Solar and Diesel Powered Pumps", National Sustainable Agriculture Information service, July 2002

[3] B. Eker, "Solar Powered Water Pumping Systems," Trakia Journal of Sciences Vol. 3, No.7, pp7 11, 2005

[4] G. Abirami, Dr. S. Pushpa Kumar, "Comparison of single phase motor with three phase motors" , International confrence on motor applications, Vol 3, Issue 4 June 2005

[5] Rajib Kumar Mandal, "Existing soalr Water Pumping Systems", International journal for sustainable engineering, vol 2, issue 3 Aug 2010

[6] Habbati Bellia, Ramdani Youcef, " A detailed modeling of photvoltaic module using MATLAB”, National Research report Algeria, 13 June 2013

[7] Ram Naresh Bharti and Rajib Kumar Mandal, "Modeling and Simulation of Maximum Power Point Tracking for Solar PV System using Peturb and observe Algorithm", International Journal of Engineering Research And Technology, ISSN 2278-0181, Vol. 3 Issue 7 July 2014.

[8] E. Kanniga, G. Abirami Sri, M.Sundhararajan , “ Implementation of a High Efficiency and Low cost Converter with Analog MPPT Using Photovoltaic Water Pumping System for Agriculture", International Journal of research in Electronic and Communication Technology, Vol.2 issue 6, Nov- Dec 2014 water pumping techniques used are discussed. The MATLAB modelling and simulation results are also included. 